\title{
Development and Evaluation of Solid Witepsol Nanoparticles for Gene Delivery
}

\section{Gen Taşınımı için Katı Witepsol Nanopartiküllerinin Geliştirilmesi ve Değerlendirilmesi}

\author{
(D) Gülşah EREL-AKBABA ${ }^{1 *}$, (D) Selen ISAR ${ }^{2 *}$, (D) Hasan AKBABA ${ }^{2}$ \\ 1'zmir Katip Çelebi University Faculty of Pharmacy, Department of Pharmaceutical Biotechnology, İzmir, Turkey \\ 2Ege University Faculty of Pharmacy, Department of Pharmaceutical Biotechnology, İzmir, Turkey
}

-: We are terribly sorry to announce that Selen Isar passed away on the date of 9 December 2020. We thank her for her contributions.

\begin{abstract}
Objectives: Gene therapy approaches have become increasingly attractive in the medical, pharmaceutical, and biotechnological industries due to their applicability in the treatment of diseases with no effective conventional therapy. Non-viral delivery using cationic solid lipid nanoparticles (cSLNs) can be useful to introduce large nucleic acids to target cells. A careful selection of components and their amounts is critical to obtain a successful delivery system. In this study, solid Witepsol nanoparticles were formulated, characterized, and evaluated in vitro for gene delivery purposes.

Materials and Methods: Solid Witepsol nanoparticles were formulated through the microemulsion dilution technique using two grades of Witepsol and three surfactants, namely Cremephor RH40, Kolliphor HS15, and Peceol. Dimethyldioctadecylammonium bromide was incorporated into the system as a cationic lipid. Twelve combinations of these ingredients were formulated. The obtained nanoparticles were then evaluated for particle size, zeta potential, DNA binding and protection ability, cytotoxicity, and transfection ability.

Results: Particle sizes of the prepared cationic cSLNs were between $13.43 \pm 0.06$ and $68.80 \pm 0.78 \mathrm{~nm}$. Their zeta potential, which is important for DNA binding efficiency, was determined at $>+40 \mathrm{mV}$. Gel retardation assays revealed that the obtained cSLNs can form a compact complex with plasmid DNA (pDNA) encoding green fluorescent protein and that this complex can protect pDNA from DNase I-mediated degradation. Cytotoxicity evaluation of nanoparticles was performed on the L929 cell line. In vitro transfection data revealed that solid Witepsol nanoparticles could effectively transfect fibroblasts.

Conclusion: Our findings indicate that solid Witepsol nanoparticles prepared using the microemulsion dilution technique are promising non-viral delivery systems for gene therapy.
\end{abstract}

Key words: Gene delivery, Witepsol, solid lipid nanoparticle, transfection, pDNA

Öz

Amaç: Etkili bir geleneksel tedavinin uygulanamadığı hastalıkların tedavisinde gen tedavisi yaklaşımları, uygulanabilirliği nedeniyle tıp, ilaç ve biyoteknoloji endüstrilerinde giderek daha çekici hale gelmiștir. Katyonik katı lipid nanopartiküller (cSLN) kullanılarak viral olmayan uygulama, büyük nükleik asitlerin hedef hücrelerin içine alınması için faydalı olabilir. Etkin bir taşıyıcı sistem elde etmek için bileşenlerin ve miktarlarının dikkatli bir şekilde seçilmesi çok önemlidir. Bu çalışmada, katı Witepsol nanopartikülleri, gen taşınması amacıyla in vitro formüle edilmiş, karakterize edilmiş ve değerlendirilmiștir.

Gereç ve Yöntemler: Katı Witepsol nanopartikülleri, iki farklı Witepsol ve üç yüzey aktif madde (Cremephor RH40, Kolliphor HS15 ve Peceol) kullanılarak mikroemülsiyon dilüsyon tekniği ile formüle edildi. Dimetildioktadesilamonyum bromür, sisteme katyonik bir lipid olarak dahil edildi. Bu bileșenlerin on iki kombinasyonu formüle edildi. Elde edilen nanopartiküller daha sonra partikül boyutu, zeta potansiyeli, DNA bağlanma ve koruma kabiliyeti, sitotoksisite ve transfeksiyon kabiliyeti açısından değerlendirildi.

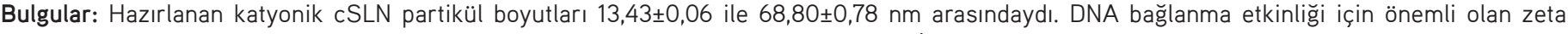
potansiyelleri $>+40 \mathrm{mV}$ olarak belirlendi. Jel retardasyon testleri, elde edilen cSLN'lerin yeșil floresan proteini kodlayan plazmit DNA (pDNA) ile kompakt bir kompleks oluşturabildiğini ve bu kompleksin pDNA'yı DNaz-I aracılı bozunmadan koruyabildiğini ortaya koydu. Nanopartiküllerin sitotoksisite değerlendirmesi, L929 hücre hattında gerçekleştirildi. In vitro transfeksiyon verileri, katı Witepsol nanopartiküllerinin fibroblastları etkili bir şekilde transfekte edebildiğini ortaya çıkardı.

Sonuç: Bu çalışma, mikroemülsiyon-dilüsyon tekniği ile hazırlanan katı witepsol nanopartiküllerin viral olmayan gen terapisi için umut verici sistemler olduğunu göstermektedir.

Anahtar kelimeler: Gen taşınımı, Witepsol, katı lipid nanopartikül, transfeksiyon, pDNA 


\section{INTRODUCTION}

Genetic treatment approaches show promise for diseases ranging from cancer to inherited illnesses. The use of naked nucleic acids is not therapeutically effective due to their hydrophilic character, anionic charge, and high molecular weight, which hinder them from crossing cell membranes.,2 To overcome these challenges, viral or non-viral gene delivery systems are used. Production of non-viral delivery systems that can carry large amounts of genetic material, have low toxicity and a low risk for immune responses, and be easily produced is one of the research areas of pharmaceutical sciences. ${ }^{3,4}$

In recent years, lipid-based carrier systems, such as liposomes, emulsions, nanostructured lipid carriers, and solid lipid nanoparticles (SLNs), have gained interest as delivery systems for gene therapy. Of these, SLNs have emerged to the forefront as promising systems in the field of non-viral gene delivery owing to their various advantages. ${ }^{5}$ Specifically, SLNs are suitable for large scale production and exhibit longterm stability. They are usually prepared by using non-toxic, biodegradable lipids. ${ }^{6,7}$ SLNs can be produced in nanosize and with cationic properties, which enable binding to nucleic acids and increase cellular influx and/or intracellular transition due to electrostatic interactions. ${ }^{8}$ The size and charge of SLNs can be modified by changing production strategies based on the purpose of production. ${ }^{9}$

Essential components for SLN formulations include lipids, emulsifiers, and an aqueous phase. The melting point of lipids is usually higher than room and body temperatures. Witepsol, which is mainly used in pharmaceutical research and development as an excipient, is a lipid that can be used for SLN formulation. A range of grades of Witepsol that comprise different proportions of triglycerides, diglycerides, and monoglycerides are commercially available to meet the requirements of pharmaceutical formulation and production and biopharmacy. Witepsol grades are classified in categories, namely $\mathrm{H}, \mathrm{W}, \mathrm{S}$, and $\mathrm{E}$. For example, Witepsol $\mathrm{H}$ series lipids consist mostly of triglycerides with a proportion of, at most, 15\% diglycerides and not more than $1 \%$ monoglycerides. They are characterized by hydroxyl values up to 15 and have a small gap between the melting and solidification temperatures. By contrast, Witepsol W series lipids consist of a mixture of triglycerides $(65 \%$ $80 \%)$, diglycerides (10\%-35\%), and monoglycerides (1\%$5 \%$ ). Their hydroxyl values are between 20-50 and exhibit a bigger difference between melting and solidification points..$^{10,11}$ Because of the diversity in their composition, Witepsol grades exhibit different characteristics; therefore, the selection of the most suitable grade during formulation development must be conducted according to these properties.11,12

Surfactants used in this study include Kolliphor HS15 (macrogol15-hydroxystearate) and Cremephor RH4O (macrogolglycerol hydroxystearate). They are non-ionic oil-in-water (o/w) solubilizing and emulsifying agents with hydrophilic-lipophilic balance (HLB) values of 14-16, making them suitable for o/w emulsion formulations.11,13 However, they exhibit different emulsifying capacity depending on the formulation components.
The aim of this study was to develop stable, solid Witepsol nanoparticles suitable for gene delivery. Therefore, the microemulsion dilution technique was employed and various formulation parameters were evaluated to produce nontoxic, biocompatible, cationic SLNs, with an optimal size and surface properties, which can be used in gene delivery. The obtained SLNs were first characterized and then complexed with plasmid DNA (pDNA). Then, protection potential against DNase I, cytotoxicity, and transfection ability were investigated. According to our findings, this study is one of the first on the development of solid Witepsol nanoparticles using the microemulsion dilution technique for gene delivery.

\section{MATERIALS AND METHODS}

\section{Materials}

Witepsol H35 [WH35; a mixture of triglycerides (65\%-80\%), diglycerides (10\%-35\%), and monoglycerides (1\%-5\%)] and Witepsol W35 (WW35; a mixture of triglycerides with a portion of, at most, $15 \%$ diglycerides and not more than $1 \%$ monoglycerides) were obtained from IOI Oleo GmbH (Germany). Cremophor RH4O (CRH40) and Kolliphor HS15 (KHS15) were donated by Baden Aniline and Soda Factory (BASF, Germany). Peceol (Pec) was a gift from Gattefosse (France). Dimethyldioctadecylammonium bromide (DDAB) was purchased from Sigma-Aldrich Co. (USA). Ethanol was purchased from Merck Co. (Germany). L929 murine skin fibroblast and CoS-7 African green monkey fibroblast cell lines were obtained from the American Type Culture Collection (USA). The alamarBlue cell proliferation assay kit was purchased from Thermo Fisher Scientific (USA). Agarose was purchased from Sigma-Aldrich Co. (USA). pEGFP-C1 plasmid DNA and maxiprep plasmid DNA purification kits were purchased from Invitrogen (USA). DNase I was purchased from Fermentas, Thermo Fischer Scientific (USA). Ultrapure water $\left(\mathrm{UPH}_{2} \mathrm{O}\right)$ was used for all experiments.

\section{Plasmid DNA}

The model plasmid pEGFP-C1 (Invitrogen, USA), which encodes the green fluorescent protein (GFP) under the CMV promoter ( $p D N A$ ), was amplified in Escherichia coli $\mathrm{DH} 5 \alpha$. The Maxiprep DNA purification kit (Invitrogen, USA) was used for plasmid purification. Plasmid integrity was evaluated by restriction enzyme digestion and visualized using a horizontal electrophoresis system. Furthermore, the purity and concentration of the plasmid were evaluated by measuring its absorbance at $260 / 280 \mathrm{~nm}$. Finally, purified plasmid DNA was diluted to $100 \mu \mathrm{g} / \mathrm{mL}$, aliquoted, and stored at $-20^{\circ} \mathrm{C}$ until use.

\section{Formulation of solid Witepsol nanoparticles}

The microemulsion dilution technique was used to develop SLNs. ${ }^{2}$ First, Witepsol was used as an internal oil phase to obtain an o/w microemulsion system. CRH40 or KHS15 and Pec (2:1, w:W) were used as surfactants (S) and ethanol as the co-surfactant (CoS). The cationic lipid DDAB was added into the solid lipid phase to achieve cationic microemulsion. ${ }^{14}$ SLNs prepared with DDAB were abbreviated as cSLN. Compositions of the designed SLNs are listed in Table 1. All components 
were weighted as that the amount of solid lipids were $50 \mathrm{mg}$ per formulation and heated to $50^{\circ} \mathrm{C}\left(10^{\circ} \mathrm{C}\right.$ above the melting temperature of Witepsol). Previously warmed $\mathrm{UPH}_{2} \mathrm{O}$ at an equivalent temperature was then added onto the lipid and S:CoS (1:1, w:w) mixture with nearly $2 \%$ of total weight increase per addition. Transparent regions were indicated on the phase diagram to determine the o/w microemulsion formation area. $A$ microemulsion consisting of $4 \%$ oil, $36 \%$ S:CoS, and $60 \%$ water was selected for further studies for all developed SLNs. The acquired hot $\mathrm{o} / \mathrm{w}$ microemulsion was then rapidly dispersed in $8 \mathrm{~mL} \mathrm{UPH}_{2} \mathrm{O}\left(0^{\circ} \mathrm{C}-4^{\circ} \mathrm{C}\right)$, stirring at $1000 \mathrm{rpm}$ at a ratio of $1: 5$ $(\mathrm{v} / \mathrm{v})$. Once hot microemulsion droplets were applied to cold water, SLNs were formed. The concentration for the final SLNs was $7.5 \mathrm{mg} / \mathrm{mL}$ for all formulations, with respect to the amounts of solid lipids.

\section{Characterization of solid Witepsol nanoparticles}

Particle size, polydispersity index (PDI), and zeta potential values of SLNs, cSLNs, and cSLN:pDNA complexes, with various formulation parameters, were measured using dynamic light scattering [(DLS), Zetasizer Nano ZS, Malvern Instruments Ltd., UK)]. ${ }^{15}$ Disposable polystyrene micro cuvettes were used to measure particle size and PDI for each sample. The zeta potential was measured in standard zeta cuvettes and calculated using the software by employing the Smoluchowski equation. Measurements were repeated at least three times for each sample.

\section{Stability of cationic, solid Witepsol nanoparticles}

Particle size and zeta potential measurements of cSLNs were followed in terms of stability for 3 months. The measurements were performed at various time intervals using DLS (Zeta sizer Nano ZS, Malvern Instruments Ltd., UK). Samples were stored at $4^{\circ} \mathrm{C}$ during this period.

\section{Gel retardation assay}

The cSLN:pDNA complexes were generated through electrostatic interactions between cationic nanoparticles and anionic pDNA. ${ }^{16}$ The complex formation ability of pDNA with cSLN was determined through $1 \%(\mathrm{w} / \mathrm{v})$ agarose gel electrophoresis. The purity and concentration of the pDNA were spectrophotometrically assayed at 260 and $280 \mathrm{~nm}$, respectively, using Nanovette (Beckman Coulter, USA). The ratio of absorbance at 260/280 $\mathrm{nm}$ was $1.752(\sim 1.8)$, indicating pDNA purity. ${ }^{17}$ A stock solution of pDNA $(100 \mu \mathrm{g} / \mathrm{mL})$ was prepared in nuclease-free $\mathrm{UPH}_{2} \mathrm{O}$. The cSLN:pDNA complexes were prepared by incubating pDNA $(100 \mu \mathrm{g} / \mathrm{mL})$ with cSLNs for 30 min at $25^{\circ} \mathrm{C}$ on a benchtop shaker for increasing cSLN:pDNA ratios $[0.5: 1,1: 1,2: 1$, and $3: 1(\mathrm{v} / \mathrm{v})]$ to enable binding of pDNA to cSLNs electrostatically. Glycerol (2\%) was added to each sample and electrophoresis was performed at $100 \mathrm{~V}$ for 60 min. Then, ethidium bromide solution $(500 \mathrm{ng} / \mathrm{mL}$ ) was used to stain the gel. The stained pDNA bands were then visualized under the ultraviolet transilluminator (Vilber Lourmat, France) to determine the optimal pDNA:cSLN ratio. Naked pDNA was used as a control.

\section{In vitro DNase I protection assay}

The protection of pDNA by cSLNs was evaluated using the in vitro DNase I protection assay. For this purpose, DNase I was added to freshly prepared cSLN:pDNA systems to get 1 IU DNase I/2.5 $\mu \mathrm{g}$ pDNA as the final concentration and incubated at $37^{\circ} \mathrm{C}$ for $30 \mathrm{~min}$. To terminate the enzymatic reaction and to obtain the release of pDNA, SDS $(1 \%, v / v)$ was added. The integrity of pDNA was visualized by horizontal gel electrophoresis. ${ }^{18}$

\section{Cytotoxicity analysis}

Cytotoxicity evaluation of the formulations was performed on L929 cell lines. Dulbecco's modified Eagle's medium

Table 1. Investigated formulation parameters and particle characterization results of Witepsol nanoparticles

\begin{tabular}{|c|c|c|c|c|c|c|}
\hline \multirow{2}{*}{ Code } & \multicolumn{2}{|c|}{ Solid lipid } & \multirow[t]{2}{*}{ DDAB } & \multicolumn{2}{|c|}{ Surfactant } & \multirow[t]{2}{*}{ pDNA } \\
\hline & WH35 & WW35 & & CRH40:Pec (2:1, w:w) & KHS15:Pec (2:1, w:w) & \\
\hline $\mathrm{SLN}_{1}$ & + & - & - & + & - & - \\
\hline $\mathrm{SLN}_{2}$ & + & - & - & - & + & - \\
\hline $\mathrm{SLN}_{3}$ & - & + & - & + & - & - \\
\hline $\mathrm{SLN}_{4}$ & - & + & - & - & + & - \\
\hline $\mathrm{cSLN}_{1}$ & + & - & + & + & - & - \\
\hline $\mathrm{cSLN}_{2}$ & + & - & + & - & + & - \\
\hline $\mathrm{cSLN}_{3}$ & - & + & + & + & - & - \\
\hline $\mathrm{cSLN}_{4}$ & - & + & + & - & + & - \\
\hline${ }^{*} \mathrm{CSLN}$ :pDNA & + & - & + & + & - & + \\
\hline${ }^{*}{ }^{*} S L N_{2}: p D N A$ & + & - & + & - & + & + \\
\hline${ }^{*} \mathrm{CSLN}_{3}: \mathrm{pDNA}$ & - & + & + & + & - & + \\
\hline${ }^{*}{ }_{C S L N}: p D N A$ & - & + & + & - & + & + \\
\hline
\end{tabular}

${ }^{*} \mathrm{CSLN}$ :pDNA, cSLN formulations complexed with pDNA. cSLN: Cationic solid lipid nanoparticle, SLN: Solid lipid nanoparticle, pDNA: Plasmid DNA, DDAB: Dimethyldioctadecylammonium bromide, Pec: Peceol 
supplemented with $10 \%$ fetal bovine serum and $2 \mathrm{mM}$ L-glutamine was used as culture medium. Penicillin and streptomycin (100 $\mathrm{Ul} / \mathrm{mL}$ penicillin, $100 \mu \mathrm{g} / \mathrm{mL}$ streptomycin) were added to prevent bacterial contamination.

Briefly, L929 cells were plated in 96-well plates at a density of $5 \times 10^{3}$ cells per well in $100 \mu \mathrm{L}$ medium and incubated for $24 \mathrm{~h}$ at $37^{\circ} \mathrm{C}$ in a humidified atmosphere of $5 \% \mathrm{CO}_{2}$. Then, the medium was renewed, the cells were treated with increasing concentrations of cSLNs $(225,450,675,900$, and $1125 \mu \mathrm{g} / \mathrm{mL}$, with respect to solid lipids), incubated for $24 \mathrm{~h}$, and washed two times with poly (butylene succinate) (PBS) $(\mathrm{pH}: 7.4)$. The alamarBlue cell viability assay was used to evaluate the proportion of viable cells. Cell viability was determined by normalizing the fluorescence of media between treated and untreated cells. ${ }^{19}$

\section{Transfection studies}

The transfection ability of the developed formulations is important for the transport of therapeutic genes into the cells. For this study, CoS-7 cells were cultured in 6-well plates at a density of $5 \times 10^{4}$ cells $/ \mathrm{mL}$ and incubated until $70 \%$ confluency. The medium was then removed and the cells were washed with PBS ( $\mathrm{pH}$ : 7.4). Fresh growth medium $(500 \mu \mathrm{L})$ was instantly added to prevent cells from desiccation. Predetermined doses of the cSLN:pDNA complex (2:1, v/v), which contains $2.5 \mu \mathrm{g}$ of pDNA, were applied to the cells based on cytotoxicity test results and incubated for $4 \mathrm{~h}$ at $37^{\circ} \mathrm{C}$ in a humidified atmosphere of $5 \% \mathrm{CO}_{2}$. Then, the medium containing the SLN suspension was replaced with fresh growth medium and cells were incubated for $48 \mathrm{~h}$ to increase GFP production. Transfection efficiency was determined $\mathrm{c}$ under a fluorescence microscope (Olympus, Japan).

\section{Statistical analysis}

Statistical analysis was performed using GraphPad Prism 6.0 (GraphPad Software, Inc., USA). Results are expressed as means \pm standard error of mean. Cytotoxicity results were analyzed using Student's t-test. The significance level was set at $p<0.05$.

\section{RESULTS AND DISCUSSION}

Due to the rapid progress in molecular biology and genetics, interest in using nanoparticles as vehicles in drug and gene delivery systems has increased. In this regard, the use of SLNs is important. During the last decade, SLNs have mostly been used as drug delivery systems. ${ }^{20-22}$ Even cationic SLNs, developed using cationic lipids, can be used as gene carrying systems; however, instances of their application in gene therapy are few. ${ }^{23-25}$ Solid lipids with relatively higher melting points, such as glyceryl behenate, behenic acid, and stearic acid (melting point $>60^{\circ} \mathrm{C}$ ), were used as the solid lipid matrix in the preparation of SLNs. ${ }^{9,14}$ However, in this study, Witepsol, which has a melting point of approximately $37^{\circ} \mathrm{C}$, has been used. The low melting point of the solid lipid matrix brings several advantages. First, the energy requirement for large scale production is decreases, thereby reducing the production cost of nanoparticle carriers and providing an advantage to enter the pharmaceutical market. ${ }^{23}$ Furthermore, following endocytosis, the genetic material-loaded SLNs presumably encounter consecutive $\mathrm{pH}$ drop in the endosome and lysosome due to the acidic character of endosomal media. ${ }^{26}$ At this step, the low melting point of Witepsol, which is close to body temperature, might facilitate the release of the genetic material into the cytoplasm compared with lipids with high melting points. ${ }^{2}$ Here, we aimed to produce SLNs using Witepsol in the solid matrix. For this purpose, plotting pseudo-ternary phase diagrams, which is the initial process of SLN production using the microemulsion dilution method, was performed at the lipid melting temperature. ${ }^{27}$

\section{Preparation of pseudo-ternary phase diagrams}

For the formation of the o/w microemulsion system, the HLB of the system was adjusted between 10 and 12 with non-toxic surfactants. One of the surfactants used in these formulations is Pec. It is a readily dispersible, solubilizing agent, consisting of a mixture of mono- and diglycerides of oleic acid. Because the HLB value of Pec is quite low (approximately 3 ), the HLB value of surfactant mixtures was increased by using $\mathrm{CRH} 40$ and $\mathrm{KHS15}$ to allow for the formation of an o/w microemulsion. The pseudoternary phase diagrams constituted by titration with $\mathrm{UPH}_{2} \mathrm{O}$ into the oil (Witepsol), S (CRH40:Pec or KHS15:Pec, 2:1, w:w), and CoS (ethanol) mixtures are presented in Figure 1. According to the construction of the phase diagram, the final formulations were selected providing microemulsion requirements, such as being o/w type and transparent, as well as having a high proportion of the solid lipid and a low proportion of S:CoS. ${ }^{28,29}$ Because the o/w microemulsion formation areas are similar for all formulations, the same ratios were selected to compare the effect of solid lipids (WH35/WW35) and S:CoS (CRH40:Pec/ KHS15:Pec). Thus, the o/w microemulsions consisting 4 wt \% solid lipid, 36 wt \% S:CoS, and 60 wt \% water were prepared and used for SLN preparation for all formulations.

\section{Physicochemical characterization}

To examine the particle size and zeta potential of nanoparticles, DLS measurements were performed. As shown in Table 2, the obtained solid Witepsol nanoparticles are in the nanometer size range (13.43-80.49 nm). Complex formation with pDNA increased the particle size of the system. SLNs without cationic lipids had a zeta potential between -2.4 and $13.7 \mathrm{mV}$. When CRH40 was used as the surfactant, the zeta potential values of nanoparticles were +13.7 and $+12.7 \mathrm{mV}$ for $\mathrm{SLN}_{1}$ and $\mathrm{SLN}_{3}$, respectively. By contrast, when KHS15 was used as the surfactant, the zeta potential decreased to -0.5 and -2.4 for $\mathrm{SLN}_{2}$ and $\mathrm{SLN}_{4}$, respectively, which is attributable to the glycerol group in CRH40. Furthermore, following DDAB incorporation, the zeta potential of cSLNs was $>40 \mathrm{mV}$ for all formulations. These results were as expected due to the cationic amphiphilic character of DDAB, which is commonly used in non-viral gene delivery studies. ${ }^{30}$ Then, the final zeta potential of the formulations was decreased by complexing with pDNA; however, it remained $>30 \mathrm{mV}$ for all four formulations. The obtained positive zeta potential of the formulations is 
a

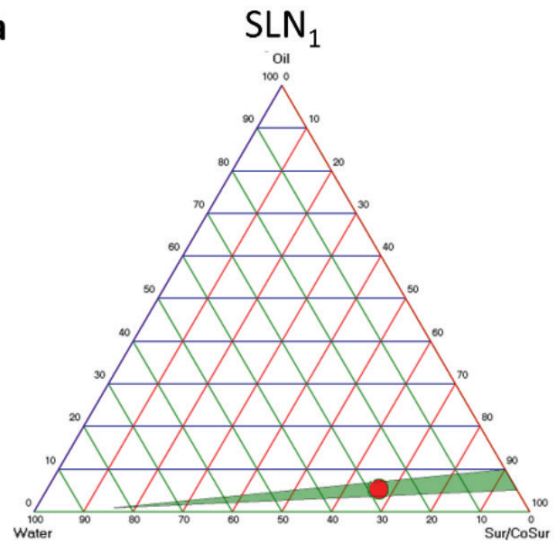

c

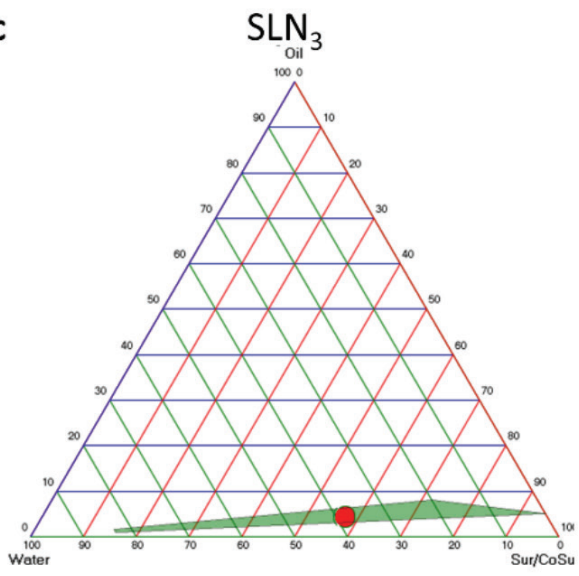

b

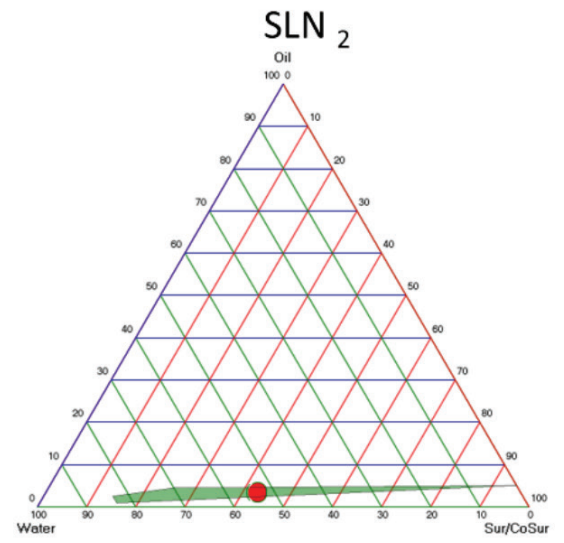

d

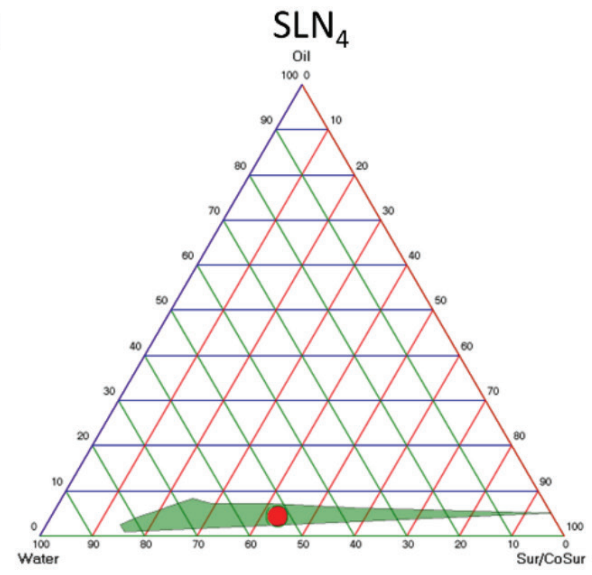

Figure 1. (a-d) Pseudo-ternary phase diagrams for different formulations, namely $\mathrm{SLN}_{1}, \mathrm{SLN}_{2}, \mathrm{SLN}_{3}$, and $\mathrm{SLN}_{4}$. The green area represents the transparent o/w microemulsion formation region

SLN: Solid lipid nanoparticle

Table 2. Particle size, PDI, and zeta potential values of SLN formulations

\begin{tabular}{|c|c|c|c|}
\hline Code & $\begin{array}{l}\text { Particle size } \\
(\mathrm{nm} \pm \mathrm{SD})\end{array}$ & PDI & $\mathrm{ZP}(\mathrm{mV} \pm \mathrm{SD})$ \\
\hline $\mathrm{SLN}_{1}$ & $23.84 \pm 0.06$ & 0.08 & $13.7 \pm 0.6$ \\
\hline $\mathrm{SLN}_{2}$ & $61.90 \pm 0.39$ & 0.13 & $-0.5 \pm 0.5$ \\
\hline $\mathrm{SLN}_{3}$ & $23.42 \pm 0.01$ & 0.04 & $12.7 \pm 4.7$ \\
\hline $\mathrm{SLN}_{4}$ & $47.87 \pm 0.28$ & 0.19 & $-2.4 \pm 0.5$ \\
\hline $\mathrm{cSLN}_{1}$ & $13.43 \pm 0.06$ & 0.62 & $43.8 \pm 1.8$ \\
\hline $\mathrm{cSLN}_{2}$ & $23.45 \pm 1.60$ & 0.91 & $47.7 \pm 0.7$ \\
\hline $\mathrm{cSLN}_{3}$ & $37.57 \pm 0.49$ & 1.00 & $42.2 \pm 2.7$ \\
\hline $\mathrm{cSLN}_{4}$ & $68.80 \pm 0.78$ & 0.36 & $41.5 \pm 1.7$ \\
\hline${ }^{*} \mathrm{CSLN} \mathrm{N}_{1}$ :pDNA & $54.44 \pm 0.54$ & 0.60 & $32.4 \pm 2.5$ \\
\hline${ }^{*} \mathrm{CSLN}_{2}: \mathrm{pDNA}$ & $80.49 \pm 1.29$ & 0.52 & $41.8 \pm 3.2$ \\
\hline${ }^{*} \mathrm{CSLN}{ }_{3}: \mathrm{pDNA}$ & $37.82 \pm 0.09$ & 0.61 & $34.0 \pm 1.6$ \\
\hline${ }^{*}{ } \mathrm{CSLN}_{4}: \mathrm{pDNA}$ & $69.50 \pm 0.45$ & 0.57 & $34.4 \pm 8.8$ \\
\hline
\end{tabular}

${ }^{*}$ cSLN:pDNA, cSLN formulations complexed with pDNA, $(n=3)$. PDI: Polydispersity index, cSLN: Cationic solid lipid nanoparticle, SLN: Solid lipid nanoparticle, SD: Standard deviation, ZP: Zeta potential, pDNA: Plasmid DNA important for achieving an interaction between the negatively charged nucleic acid and cell membrane for transfection. ${ }^{31,32}$ The PDI values of the produced SLNs increased after DDAB was incorporated into the system as a cationic lipid. However, polydispersity of the formulation decreased after complex formation with pDNA occurred. Particle sizes of the final cSLN:pDNA vector systems were $\langle 100 \mathrm{~nm}$, which is necessary for i.v. injection. Moreover, they are small enough to provide stability to the dispersal system owing to Brownian motion. ${ }^{33}$

The physicochemical stability of the developed cSLNs was evaluated. For this experiment, cSLNs were stored at $4^{\circ} \mathrm{C}$ and particle size and zeta potential were measured for up to 90 $d$ (Table 3). The results revealed that particle size and zeta potential of cSLNs remained stable for $21 \mathrm{~d}$. Particle size of cSLNs increased dramatically within $90 \mathrm{~d}$. The particle size of only cSLN ${ }_{3}$ remained at less than $100 \mathrm{~nm}$. Thus, the developed formulations can be used for complexation with pDNA for at least $21 \mathrm{~d}$ because their particle size is $\langle 100 \mathrm{~nm}$ and zeta potential is $>40 \mathrm{mV}^{34}$

\section{Gel retardation assay}

The gel retardation assay is used to evaluate the nucleic acidbinding ability of cationic nanoparticles. ${ }^{16}$ cSLNs were evaluated for their complex formation ability with pDNA using the agarose 
gel retardation assay to identify the optimal cSLN:pDNA ratio. The migration of naked pDNA and cSLN:pDNA complexes for different Witepsol nanoparticles in agarose gel is shown in Figure 2. The obtained cSLNs showed pDNA binding ability and the migration of pDNA in agarose gel stopped when the ratio of cSLN:pDNA reached 2:1 (v/v) for all cSLNs.

Protection ability of nanoparticles against DNase I degradation The agarose gel photograph of cSLN:pDNA complexes incubated with DNase I is shown in Figure 3. Lane 1 contains the untreated
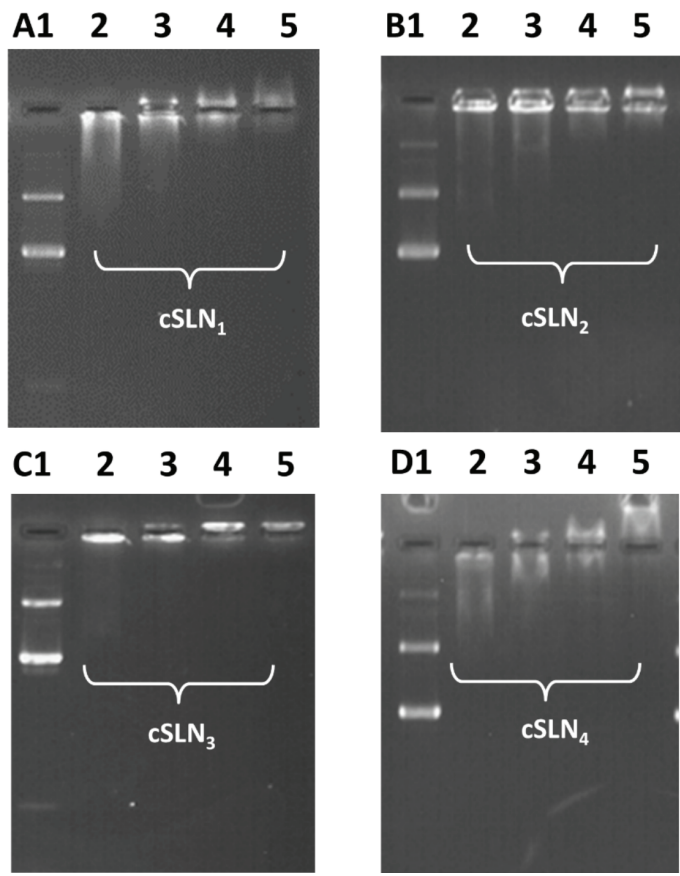

Figure 2. Agarose gel photograph of complexes containing a constant amount of pDNA and increasing amounts of $\mathrm{cSLN}_{1}, \mathrm{cSLN}_{2}, \mathrm{cSLN}_{3}$, or cSLN at $0.5: 1,1: 1,2: 1$, and $3: 1(\mathrm{v} / \mathrm{v})$, respectively

pDNA: Plasmid DNA, cSLN: Cationic solid lipid nanoparticle

\section{Table 3. The physicochemical stability of cSLNs at $4^{\circ} \mathrm{C}$}

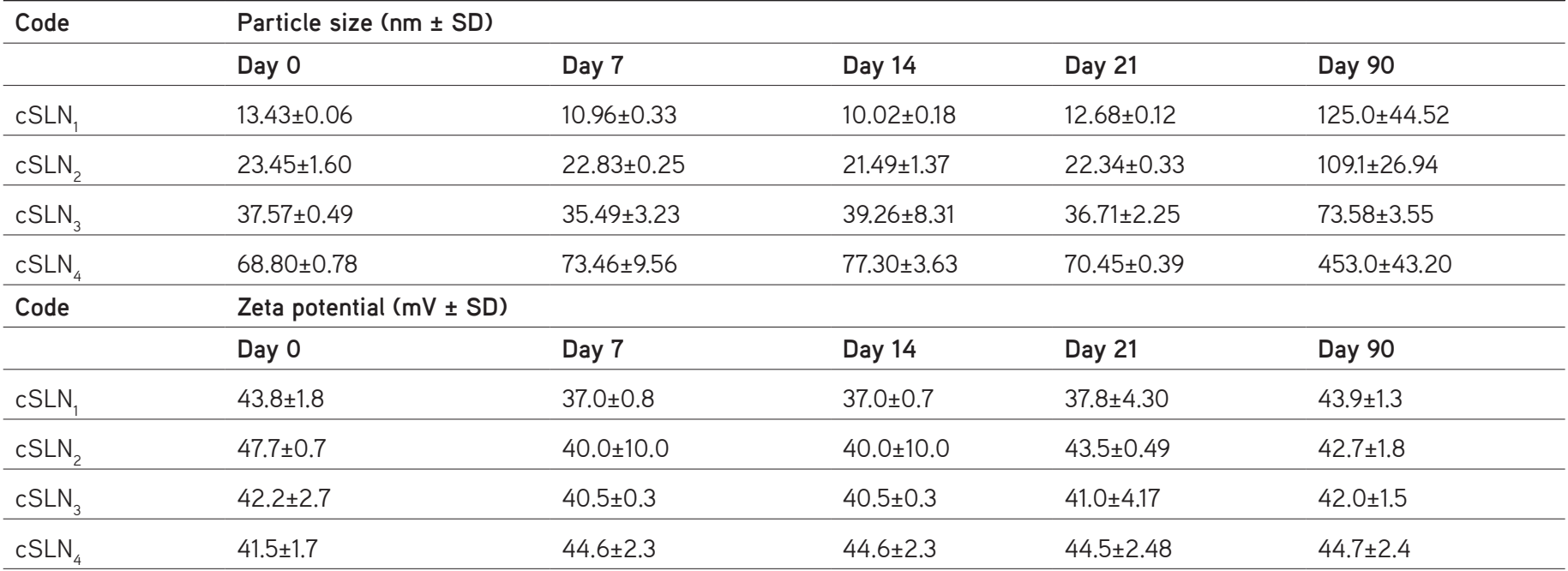

cSLN: Cationic solid lipid nanoparticle, SD: Standard deviation plasmid (negative control). As seen in lane 2, naked pDNA was completely digested by DNase I. Lanes 3-5 indicate the protection of the cSLN formulations against DNase I at three cSLN:pDNA ratios, namely 1:1, 2:1, and 3:1 (v:v). This evidence confirmed that the obtained cSLNs efficiently protected the pDNA from DNase I-mediated degradation. ${ }^{35}$

\section{Cytotoxicity}

The cytotoxicity assay was performed to identify non-toxic doses of the obtained nanoparticles before transfection. The results
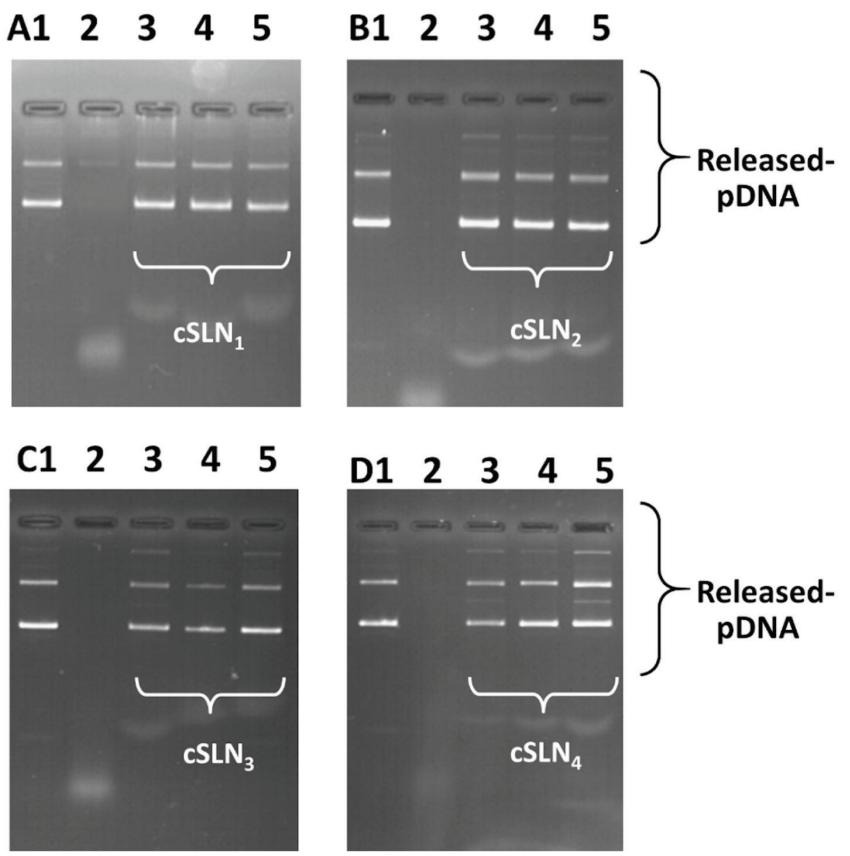

Figure 3. DNase I protection of cSLN:pDNA complexes. (1: Control pDNA; 2 : Naked pDNA incubated with DNase I; 3-5: pDNA released from cSLN:pDNA complexes following incubation with DNase I for cSLN:pDNA ratios 1:1, 2:1, and 3:1 (v:v), respectively. (Lanes A1-5 for $\mathrm{cSLN}_{1}$, lanes B1-5 for $\mathrm{CSLN}_{2}$, lanes C1-5 for $\mathrm{CSLN}_{3}$, and lanes D1-5 for $\mathrm{CSLN}_{4}$ )

cSLN: Cationic solid lipid nanoparticle, pDNA: Plasmid DNA 
obtained from the alamarBlue cytotoxicity assay on the L929 cell line supported that all excipients used in this study have low cytotoxicity. Significant cytotoxicity was not determined on L929 cells in at concentrations ranging from 225 to $1125 \mu \mathrm{g} /$ $\mathrm{mL}$. The applied doses showed $>70 \%$ cell viability, which is considered the minimum reference cell viability dose for further transfection studies. ${ }^{33}$ Furthermore, concentration dependent cytotoxicity was observed for all formulations (Figure 4).

\section{Cellular uptake studies}

The uptake of Witepsol nanoparticles in the CoS-7 cell line was determined using the pEGFP-C1 plasmid and visually investigated under a fluorescence microscope (Figure 5). Green shows the fluorescence signal from GFP. According to transfection results, all obtained formulations have transfection ability. ${ }^{36,37}$ Since the developed nanoparticles

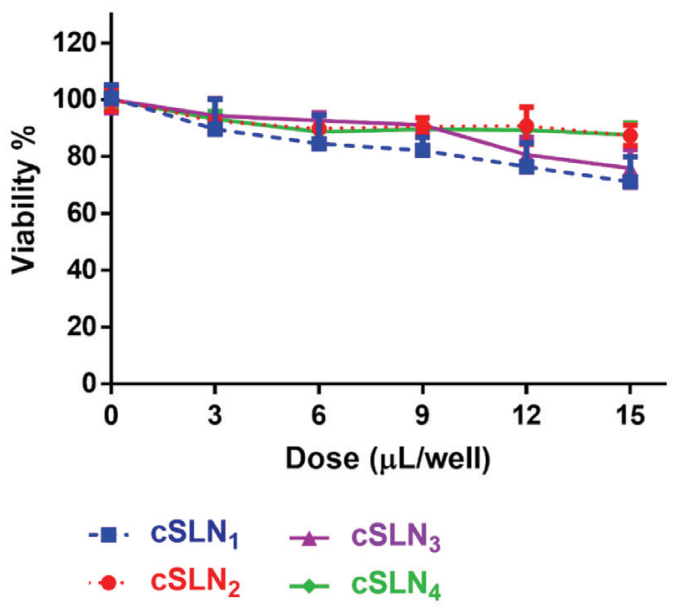

Figure 4. Viability of L929 cells exposed to cSLN formulations. Each condition was tested in at least four replicates for $24 \mathrm{~h}$

cSLN: Cationic solid lipid nanoparticle
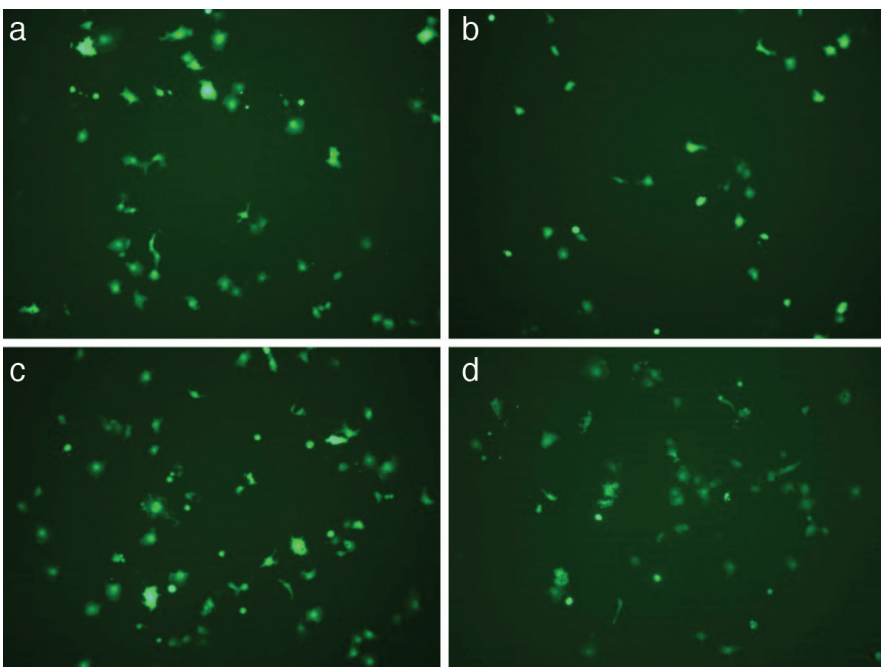

Figure 5. Images of GFP-positive cells following cSLN:pEGFP-C1 application, observed using inverted fluorescence microscopy after $48 \mathrm{~h}$ of transfection for $\mathrm{cSLN}_{1}(\mathrm{a}), \mathrm{cSLN}_{2}$ (b), cSLN $\mathrm{cL}_{3}$ (c), and $\mathrm{cSLN}_{4}$ (d) pEGFP-C1 complexes

GFP: Green fluorescent protein, cSLN: Cationic solid lipid nanoparticle showed efficient transfection in cell culture, they can be used for different genetic diseases by loading disease specific therapeutic genes.

\section{CONCLUSION}

We prepared and characterized solid Witepsol nanoparticles. The obtained cationic nanoparticles exhibited pDNA binding and protection ability. The characterization of formulations in terms of particle size, zeta potential, and PDI revealed that the obtained nanoparticles are in the nanometer size range. Cytotoxicity results confirmed the suitability of the nanoparticles for gene delivery. Transfection studies showed that the developed nanoparticles can carry genetic material into cells efficiently. Thus, solid Witepsol nanoparticles can be considered promising delivery vehicles for non-viral gene therapy.

\section{ACKNOWLEDGMENTS}

This study has been financially supported by the Scientific and Technological Research Council of Turkey (TUBITAK) under grant code $218 S 840$ and İzmir Katip Çelebi University Research Fund under grant code 2020-ÖDL-ECZF-0001. This paper is dedicated to the memory of our co-author dear Selen Isar, who sadly passed away on Wednesday, December $9^{\text {th }}, 2020$.

Conflicts of interest: No conflict of interest was declared by the authors. The authors alone are responsible for the content and writing of the paper.

\section{REFERENCES}

1. Southwell AL, Skotte NH, Bennett CF, Hayden MR. Antisense oligonucleotide therapeutics for inherited neurodegenerative diseases. Trends Mol Med. 2012;18:634-643.

2. Erel-Akbaba G, Carvalho LA, Tian T, Zinter M, Akbaba H, Obeid PJ, Chiocca EA, Weissleder R, Kantarci AG, Tannous BA. Radiation-induced targeted nanoparticle-based gene delivery for brain tumor therapy. ACS Nano. 2019;13:4028-4040.

3. Govindarajan S, Kitaura K, Takafuji M, Ihara H,Varadarajan KS, Patel AB, Gopal V. Gene delivery into human cancer cells by cationic lipidmediated magnetofection. Int J Pharm. 2013;446:87-99.

4. Salva E, Turan SÖ, Eren F, Akbuğa J. The enhancement of gene silencing efficiency with chitosan-coated liposome formulations of siRNAs targeting HIF-1 $\alpha$ and VEGF. Int J Pharm. 2014;478:147-154.

5. Carrillo C, Sánchez-Hernández N, García-Montoya E, Pérez-Lozano P, Suñé-Negre JM, Ticó JR, Suñé C, Miñarro M. DNA delivery via cationic solid lipid nanoparticles (SLNs). Eur J Pharm Sci. 2013;49:157-165.

6. Bhattacharyya S, Reddy P. Effect of surfactant on azithromycin dihydrate loaded stearic acid solid lipid nanoparticles. Turkish J Pharm Sci. 2019;16:425-431.

7. Amasya G, Sengel Turk CT, Badılı U, Tarımcı N. Development and statistical optimization of solid lipid nanoparticle formulations of fluticasone propionate. Turkish J Pharm Sci. 2020;17:359-366.

8. Guo J, Evans JC, O'Driscoll CM. Delivering RNAi therapeutics with nonviral technology: A promising strategy for prostate cancer? Trends Mol Med. 2013;19:250-261. 
9. Sznitowska M, Wolska E, Baranska H, Cal K, Pietkiewicz J. The effect of a lipid composition and a surfactant on the characteristics of the solid lipid microspheres and nanospheres (SLM and SLN). Eur J Pharm Biopharm. 2017;110:24-30.

10. Campos DA, Madureira AR, Gomes AM, Sarmento B, Pintado MM. Optimization of the production of solid Witepsol nanoparticles loaded with rosmarinic acid. Colloids Surfaces B Biointerfaces. 2014;115:109117.

11. Nepal PR, Han HK, Choi HK. Preparation and in vitro-in vivo evaluation of Witepso ${ }^{\circledR} \mathrm{H} 35$ based self-nanoemulsifying drug delivery systems (SNEDDS) of coenzyme Q10. Eur J Pharm Sci. 2010;39:224-232.

12. Calis S, Sumnu M, Hincal AA. Effect of suppository bases on the release properties of a potent antimicrobial agent. Pharmazie. 1994;49:336-339.

13. Akhtar N, Khan RA, Mohammad SAA, Yusuf M, Singh V, Mohammed H, Alomar MS, Abdellatif AAH, Naz M, Khadri H. Self-Generating nanoemulsifying technology for alternatively-routed, bioavailability enhanced delivery, especially for anti-cancers, anti-diabetics, and miscellaneous drugs. J Drug Deliv Sci Technol. 2020;58:101808.

14. de Jesus MB, Zuhorn IS. Solid lipid nanoparticles as nucleic acid delivery system: Properties and molecular mechanisms. J Control Release. 2015;201:1-13.

15. Erel G, Kotmakçı M, Akbaba H, Sözer Karadağı S, Kantarcı AG. Nanoencapsulated chitosan nanoparticles in emulsion-based oral delivery system: In vitro and in vivo evaluation of insulin loaded formulation. J Drug Deliv Sci Technol. 2016;36:161-167.

16. Büyükköroğlu G. Development of solid lipid gene delivery system. Turkish J Pharm Sci. 2016;13:249-258.

17. Lucena-Aguilar G, Sánchez-López AM, Barberán-Aceituno C, CarrilloÁvila JA, López-Guerrero JA, Aguilar-Quesada R. DNA Source Selection for Downstream Applications Based on DNA Quality Indicators Analysis. Biopreserv Biobank. 2016;14:264-270.

18. Akbaba H, Selamet $\mathrm{Y}$, Kantarcı AG. In situ production of cationic lipid coated magnetic nanoparticles in multiple emulsions for gene delivery. Marmara Pharm J. 2016;20:72-78.

19. Wang Y, Malcolm DW, Benoit DSW. Controlled and sustained delivery of siRNA/NPs from hydrogels expedites bone fracture healing. Biomaterials. 2017;139:127-138.

20. Gaspar DP, Serra C, Lino PR, Gonçalves L,Taboada P, Remuñán-López C. Almeida AJ. Microencapsulated SLN: An innovative strategy for pulmonary protein delivery. Int J Pharm. 2017;516:231-246.

21. Müller RH, Mäder K, Gohla S. Solid lipid nanoparticles (SLN) for controlled drug delivery - A review of the state of the art. Eur J Pharm Biopharm. 2000;50:161-177.

22. Pardeike J, Hommoss A, Müller RH. Lipid nanoparticles (SLN, NLC) in cosmetic and pharmaceutical dermal products. Int $\mathrm{J}$ Pharm. 2009;366:170-184.

23. Küçüktürkmen $B, B o z k ı r ~ A$. Development and characterization of cationic solid lipid nanoparticles for co-delivery of pemetrexed and miR-21 antisense oligonucleotide to glioblastoma cells. Drug Dev Ind Pharm. 2018;44:306-315.
24. del Pozo-Rodríguez A, Pujals S, Delgado D, Solinís MA, Gascón AR, Giralt E, Pedraz JL. A proline-rich peptide improves cell transfection of solid lipid nanoparticle-based non-viral vectors. J Control Release. 2009;133:52-59.

25. Rassu G, Soddu E, Posadino AM, Pintus G, Sarmento B, Giunchedi P, Gavini E. Nose-to-brain delivery of BACE1 siRNA loaded in solid lipid nanoparticles for Alzheimer's therapy. Colloids Surfaces B Biointerfaces. 2017;152:296-301.

26. Resnier P, Montier T, Mathieu V, Benoit JP, Passirani C. A review of the current status of siRNA nanomedicines in the treatment of cancer. Biomaterials. 2013;34:6429-6443.

27. Mäder K, Mehnert W. Solid lipid nanoparticles: production, characterization and applications. Adv Drug Deliv Rev. 2001;47:165-196.

28. Geszke-Moritz M, Moritz M. Solid lipid nanoparticles as attractive drug vehicles: Composition, properties and therapeutic strategies. Mater Sci Eng C Mater Biol Appl. 2016;68:982-994.

29. Akbaba H, Kantarcı AG, Erel Akbaba G. Development and in vitro evaluation of positive-charged solid lipid nanoparticles as nucleic acid delivery system in glioblastoma treatment. Marmara Pharm J. 2018;22:299-306.

30. Domenici F, Castellano C, Dell'Unto F, Congiu A. Temperature-dependent structural changes on DDAB surfactant assemblies evidenced by energy dispersive $X$-ray diffraction and dynamic light scattering. Colloids Surfaces B Biointerfaces. 2012;95:170-177.

31. Lei $Y$, Tang L, Xie Y, Xianyu Y, Zhang L, Wang P, Hamada Y, Jiang K, Zheng W, Jiang X. Gold nanoclusters-assisted delivery of NGF siRNA for effective treatment of pancreatic cancer. Nat Commun. 2017;8:15130.

32. Gooding M, Malhotra M, McCarthy DJ, Godinho BMDC, Cryan JF, Darcy R, O'Driscoll CM. Synthesis and characterization of rabies virus glycoprotein-tagged amphiphilic cyclodextrins for siRNA delivery in human glioblastoma cells: in-vitro analysis. Eur J Pharm Sci. 2015;71:8092.

33. Akbaba H, Erel Akbaba G, Kantarcl AG. Development and evaluation of antisense shRNA-encoding plasmid loaded solid lipid nanoparticles against 5- $\alpha$ reductase activity. J Drug Deliv Sci Technol. 2018;44:270277.

34. Cavalli R, Caputo O, Eugenia M, Trotta M, Scarnecchia C, Gasco MR. Sterilization and freeze-drying of drug-free and drug-loaded solid lipid nanoparticles. Int J Pharm. 1997;148:47-54.

35. Kumari M, Liu CH, Wu WC. Efficient gene delivery by oligochitosan conjugated serum albumin: Facile synthesis, polyplex stability, and transfection. Carbohydr Polym. 2018;183:37-49.

36. Xiao W, Chen X, Yang L, Mao Y, Wei Y, Chen L. Co-delivery of doxorubicin and plasmid by a novel FGFR-mediated cationic liposome. Int J Pharm. 2010;393:119-126.

37. Lacroix C, Humanes A, Coiffier C, Gigmes D, Verrier B, Trimaille T. Polylactide-Based Reactive Micelles as a Robust Platform for mRNA Delivery. Pharm Res. 2020;37:30. 